\title{
Incorporating Hofstede' National Culture in Human Factor Analysis and Classification System (HFACS): Cases of Indonesian Aviation Safety
}

\author{
Gradiyan Budi Pratama, Ari Widyanti*, and Iftikar Zahedi Sutalaksana \\ Department of Industrial Engineering, Bandung Institute of Technology (ITB), Bandung, Indonesia
}

\begin{abstract}
National culture plays an important role in the application of ergonomics and safety. This research examined role of national culture in accident analysis of Indonesian aviation using framework of Human Factors Analysis and Classification System (HFACS). 53 Indonesian aviation accidents during year of 2001-2012 were analyzed using the HFACS framework by authors and were validated to 14 airtransport experts in Indonesia. National culture is viewed with Hofstede' lens of national culture. Result shows that high collectivistic, low uncertainty avoidance, high power distance, and masculinity dimension which are characteristics of Indonesian culture, play an important role in Indonesian aviation accident and should be incorporated within HFACS. Result is discussed in relation with HFACS and Indonesian aviation accident analysis.
\end{abstract}

\section{Introduction}

In global aviation accident, Shappell \& Wiegmann (2005) stated that human factors contribute to $80-90 \%$ of those accident. Moreover, it has been known that aviationaccident rates differ across countries and regions. In general, developing countries in Asia and Africa have higher accident rates than Western American or Western Europe. The reason why developing countries have higher aviation accident rate than developed countries relates with mismatch between aviation system and the user. It should be noted that majority of the aviation system has been developed from a Western (North American/Western European) perspective [10]. The most possible cause of aviation accident in developing countries in relation with the mismatch is the different national culture.

National culture, defined as collective mental programming of the mind that distinguishes the members of one group or category of people from others (in this case, the group is a nation, [3]) plays important role in many ergonomics application. For example, in mental workload measures, national culture influence the sensitivity of mental workload measure between Eastern and Western culture, both for subjective measures (see [9] for further review) as well as objective measures (see [18] for further review).

Hofstede [3-5] proposed six dimensions of national culture: power distance (PD), uncertainty avoidance (UAI), individualism (IDV), masculinity (MAS), Longterm orientation (LTO), and indulgence vs. retraint (IVR). $\mathrm{PD}$ is the extent to which member of society accept equality among them in society. High PD culture is characterized by inequality between ordinate and subordinate. UAI is the extent to which the members of society perceive a threat in uncertain or unfamiliar situations. High UAI culture is characterized by acceptance of possibility of such situations by no strict behavioral codes, laws and rules, and approval of deviant opinion. IDV is the extent to which society reinforce individual or collective achievement and interpersonal relationship. High IDV culture is characterized by high respect of individual rights and individual tends to form a larger number of moderately distant relationship. MAS is the extent to which the society distinguish male and female in achievement, control, and power. High MAS culture is characterized by male domination. LTO related to the choice of focus for people's efforts: the future or the present and past. High LTO is characterized by perseverance, thrift, ordering relationships by status, and having a sense of shame. IVR related to the gratification versus control of basic human desires related to enjoying life. High indulgence is characterized by allowing relatively free gratification of basic and natural human desires related to enjoying life and having fun.

There are many research have been conducted to explore the relationship between national culture and aviation safety, i.e., different cultures hypothesized to be differ in promoting aviation safety. According to Li and Harris (2007), the short-term orientation culture (i.e., the US) seems to be superior for promoting aviation safety than the long-term orientation culture (i.e. Taiwan) [12]. Jing et al. (2001) also offers indirect proof of the relationship between world aircraft accident rates and national cultural background, in which authoritarianism explain more than half the variance in accident rates [8].

\footnotetext{
* Corresponding author: widyanti@mail.ti.itb.ac.id
} 
They showed that the 'normal' activities in the cockpit designed in the West are highly vulnerable to an authoritarian mentality

The crucial role of national culture in aviation safety raises a need of accident analysis tool which incorporating national culture in the analysis of aviation accident. One tool that has been applied in investigating aviation accident is Human Factors Analysis and Classification System (HFACS) [14-16]. HFACS is based on Reasons' model of human error (Reason, 1990) as can be seen in Figure 1. According to Reason, active failures are related with the performance of operators in complex system, whereas latent failures are characterized as inadequacies or miss-specifications that lie within a system for a long time and only triggered when combined with other factors. The first level of HFACS is "unsafe acts of operators" and can be classified into two categories that are errors and violation. The second level is "precondition for unsafe acts" related with the latent failures within the causal sequence of events. The third level is "unsafe supervision" which traces the causal chain of events producing unsafe acts up to the level of the frontline supervisor. The fourth level is "organizational influences" which describes upper level management' fallible decisions that directly influence both supervisory and front-line operators' practices.

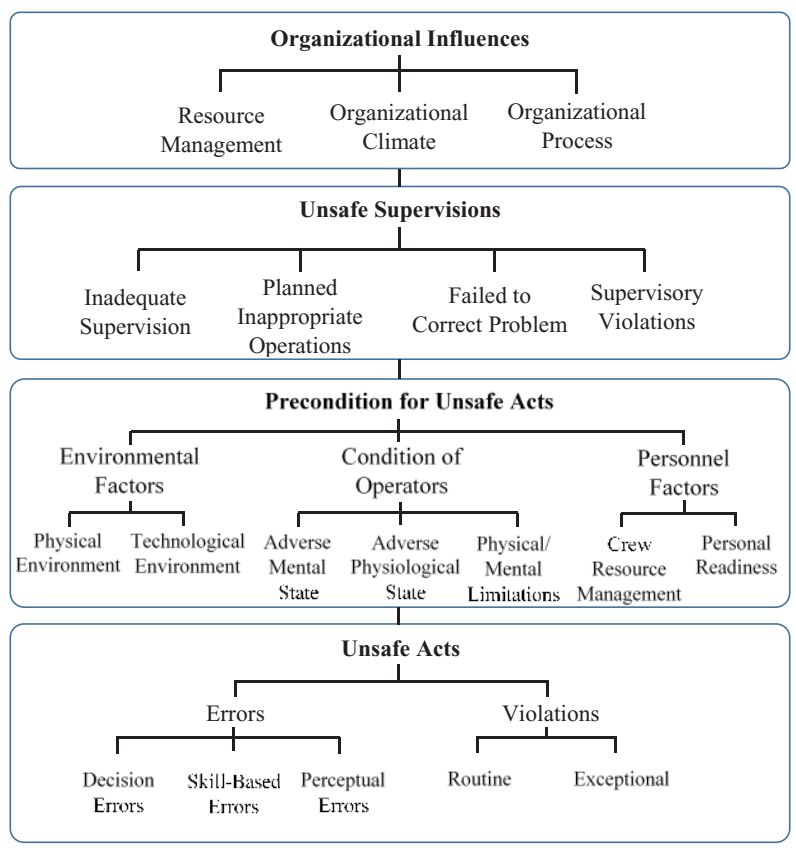

Fig. 1. Human Factors Analysis and Classification System

Indonesia, a fast growing developing countries in Asia, has high aviation accident among other countries, even worst, Indonesian airlines rank lowest in world for safety, after Brazil and China (www.aviation-safety.net). Although more modern planes and better navigation equipment have helped cut crash rates, the number of fatal crashes hasn't changed very much. Indonesian National Transportation Safety Committee (Komite Nasional Keselamatan Transportasi/KNKT in Indonesian) stated that human factors contribute to $52 \%$ of Indonesian aviation accident. Preliminary interview with KNKT reveal many factors related to the role of human factors in Indonesian aviation accident, including Indonesian national culture. Regarding national culture, Hofstede' study [3] as well as Johnson \& Widyanti' study [9] found that Indonesia has high PD, low UAI, low IDV, high MAS, low LTO, and high IVR.

The purpose of this study is to observe role of culture in Indonesian aviation safety and to incorporate national culture in HFACS. Accident reports have been observed and experts or accident investigators were asked to apply HFACS in these accident reports with possible cultural role in the accident investigation.

\section{Method}

\subsection{Material}

Report of 53 accidents or near-miss accidents in Indonesian aviation were obtained from Indonesian National Committee of Transportation Safety (Komite Nasional Keselamatan Transportasi/KNKT in Indonesian) between 2001 and 2012. The report of KNKT consists of chronology of the accident as well as general report of the cause(s) of the accident.

\subsection{Participants}

There are 14 participants in this study. They are two lecturers of engineering aviation department Bandung Institute of Technology (ITB), one director of flight carrier, one senior pilot, one senior flight engineer, one operational risk and hazard manager, one chief pilot and senior manager incident management, one senior manager corporate quality assurance, IOSA compliance manager, senior manager safety information management, one commercial director of flight carrier, one senior flight attendant and senior manager safety information management. Participation was voluntarily.

\subsection{Procedure}

Accident analysis report from KNKT is used as a base in identification and classification of accident based on HFACS taxonomy. In addition, in-depth interviews with participants were conducted to address specific events in which participants were ever involved or well-informed. The participants were asked to make a comment on aviation safety in Indonesia in general, and then relate concrete situation in one or two specific accidents. There are also some participants described multiple independent accident during an interview session. Interviews were audiotaped and then transcribed. The interviews for each participants is about $30-60$ minutes.

From the accident report from KNKT and transcript, result of interviews were identified and classified based on HFACS taxonomy. The initial classification was conducted by the second author and discussed with first author until consensus was reached. An additional reliability check was conducted by confirmed the classification to all participants. Discussion and 
consensus method was applied in HFACS taxonomy for 53 accident reports in Indonesian aviation.

Based on classification of HFACS, Hofstede' indicator [3] was used as a guide for the identification process of cultural factors in each layer of HFACS. Hofstede describes 10 indicators of PDI, 7 indicators of IDV, 10 indicators of MAS, 17 indicators of UAI, 12 indicators of LTO, 10 indicators of IVR. For example, indicators of small power distance are: (1) use of power should be legitimate and is subject to criteria of good and evil, (2) parents treat children as equal, (3) older people are neither respected nor feared, (4) student-centered education, (5) hierarchy means inequity of roles, established for convenience, (6) subordinate expect to be consulted, (7) pluralist governments based on majority vote and change peacefully, (8) corruption rare and scandals end political careers, (9) income distribution in society rather even, (10) religions stressing equality of believers. (see Hofstede, 2011 for further review).

\section{Results and Discussions}

For the 53 accident reports, application of HFACS based on analysis of KNKT and interview of participants, following by classification of accident cause conducted by first author and second author, confirmed by all participants, can be seen in Table 1 .

Table 1. Result of HFACS for 53 Indonesian aviation accidents

\begin{tabular}{|c|c|c|c|}
\hline Sub Level 1 & Sub Level 2 & Number & $\%$ \\
\hline \multirow{3}{*}{ Errors } & Decision error & 22 & 9.09 \\
\hline & $\begin{array}{l}\text { Skill-based } \\
\text { error }\end{array}$ & 38 & 15.70 \\
\hline & $\begin{array}{l}\text { Perceptual } \\
\text { errors }\end{array}$ & 10 & 4.13 \\
\hline \multirow{2}{*}{ Violations } & Routine & 4 & 1.65 \\
\hline & Exceptional & 2 & 0.83 \\
\hline \multirow{2}{*}{$\begin{array}{l}\text { Environment } \\
\text { factors }\end{array}$} & Physical & 16 & 6.61 \\
\hline & Technological & 14 & 5.79 \\
\hline \multirow{3}{*}{$\begin{array}{l}\text { Condition of } \\
\text { operators }\end{array}$} & $\begin{array}{l}\text { Adverse mental } \\
\text { states }\end{array}$ & 21 & 8.68 \\
\hline & $\begin{array}{l}\text { Adverse } \\
\text { physiological } \\
\text { states }\end{array}$ & 0 & 0 \\
\hline & $\begin{array}{l}\text { Physical/mental } \\
\text { limitations }\end{array}$ & 8 & 3.31 \\
\hline \multirow{2}{*}{$\begin{array}{l}\text { Personnel } \\
\text { factors }\end{array}$} & $\begin{array}{l}\text { Crew resource } \\
\text { management }\end{array}$ & 23 & 9.50 \\
\hline & $\begin{array}{l}\text { Personal } \\
\text { readiness }\end{array}$ & 0 & 0 \\
\hline \multicolumn{2}{|c|}{ Inadequate supervision } & 18 & 7.44 \\
\hline \multicolumn{2}{|c|}{ Planned inappropriate operations } & 8 & 3.31 \\
\hline \multicolumn{2}{|c|}{ Failed to correct problem } & 7 & 2.89 \\
\hline \multicolumn{2}{|c|}{ Supervisory violations } & 5 & 2.07 \\
\hline \multicolumn{2}{|c|}{ Resource management } & 13 & 5.37 \\
\hline \multicolumn{2}{|c|}{ Organizational climate } & 3 & 1.24 \\
\hline \multicolumn{2}{|c|}{ Organizational process } & 30 & 12.40 \\
\hline
\end{tabular}

From table 1, it can be seen that skill-based error own first rank of accident cause in HFACS analysis, followed by organizational process, crew resource management, and decision errors. Using Hofstede' indicators, cultural factors that contribute to HFACS' layer have been identified as can be seen in Table 2. It can be seen that national culture that plays an important role in Indonesian aviation safety is PD, IDV, MAS, and UAI. Result of this study supports previous study. As stated by Hofstede [4] and Helmreich \& Merrit [2], some aspects of national culture that have been identified as crucial in aviation include IDV, PDI, UAI.

There are 3 Indonesian aviation accidents happened in 2007, 2011 and 2012 which correlate with high PD and decision error. In these three accidents, senior pilot ignores alert from instrument as well as warning from copilot. Participants agree that it is very common in a cockpit that senior pilot have over confidence with his capability and feel superior to co-pilot. Ignoring co-pilot is usually happen. This is in line with common facts of high PD in Indonesia. According to Helmreich (1999) high PD is characterized by unwillingness to question the decision or action of leaders, which leads to accident [1].

Table 2. Hofstede' cultural factors identified in HFACS for 53 Indonesian aviation accidents.

\begin{tabular}{|l|l|l|l|l|l|l|l|l|l|l|l|l|}
\hline \multirow{2}{*}{$\begin{array}{l}\text { HFACS } \\
\text { Taxonomy }\end{array}$} & \multicolumn{7}{|c|}{ Hofstede' Culture Dimensions } \\
\hline & \multicolumn{1}{|c|}{ PD } & \multicolumn{1}{|c|}{ IDV } & \multicolumn{2}{|c|}{ MAS } & \multicolumn{2}{|c|}{ UA } & \multicolumn{2}{|c|}{ LTO } & \multicolumn{2}{|c|}{ IVR } \\
\hline & H & H & L & H & L & H & L & H & L & H & L \\
\hline Rsc. Mgt & & & & & & & & 8 & & & & \\
\hline Org.Clim. & & & & & & 1 & & 2 & & & & \\
\hline Org. Process & & & & & & 1 & & 16 & & & & \\
\hline $\begin{array}{l}\text { Inadqt. } \\
\text { Sprvision }\end{array}$ & & & & & & & & 5 & & & & \\
\hline $\begin{array}{l}\text { Planned } \\
\text { Inapp. Opt }\end{array}$ & & & & & & & & 5 & & & & \\
\hline $\begin{array}{l}\text { Fail to } \\
\text { Correct }\end{array}$ & 1 & & & & & 1 & & 5 & & & & \\
\hline $\begin{array}{l}\text { Supervisory } \\
\text { Violations }\end{array}$ & & & & & & 1 & & 3 & & & & \\
\hline $\begin{array}{l}\text { Physical } \\
\text { Enviro. }\end{array}$ & & & & & & & & 1 & & & & \\
\hline $\begin{array}{l}\text { Techno. } \\
\text { Enviro. }\end{array}$ & & & & & & & & & & & & \\
\hline $\begin{array}{l}\text { Adverse } \\
\text { Mental Sts. }\end{array}$ & 1 & & & & & & & 3 & & & & \\
\hline $\begin{array}{l}\text { Adverse } \\
\text { Physio Sts. }\end{array}$ & & & & & & & & & & & & \\
\hline $\begin{array}{l}\text { Physical/ } \\
\text { Mental Lim. }\end{array}$ & & & & & & & & & & & \\
\hline CRM & 3 & & & & 4 & & 2 & & & & \\
\hline $\begin{array}{l}\text { Personal } \\
\text { Readiness }\end{array}$ & & & & & & & & & & & \\
\hline $\begin{array}{l}\text { Skill-based } \\
\text { Errors }\end{array}$ & & & & & & & & & & & \\
\hline $\begin{array}{l}\text { Decision } \\
\text { Errors }\end{array}$ & 3 & & & & 1 & & 13 & & & & \\
\hline $\begin{array}{l}\text { Perceptual } \\
\text { Errors }\end{array}$ & & & & & & & & & & & & \\
\hline $\begin{array}{l}\text { Exceptional } \\
\text { Violations }\end{array}$ & & & & & & & & 4 & & & & \\
\hline $\begin{array}{l}\text { Routine } \\
\text { Violations }\end{array}$ & & & & & & & & 4 & & & & \\
\hline
\end{tabular}

UAI plays an important role in the Indonesian aviation safety since 13 accidents have been influenced by this cultural dimension. Such an accident happened because pilot take a risk by flying in bad weather because 
experiences teach him that flying during bad weather is safe. Another pilot force to land during unstable condition of aircraft. The tendency to take a risk is related with low UAI index of Indonesian culture which give tolerance to risk and use common sense in some situation. UAI was also identified in organizational process for 13 aviation accidents. According to Helmreich (1999), low UAI may be more prone to disregard SOPs [1].

Indonesian low of IDV also influence 1 aviation accident. There is a tendency that a decision must be discussed first and consensus must be reached upon the decision, so that decision cannot be taken immediately, which in turn affect safety. In term of IDV, Helmreich (2000) stated that IDV is contributing to aviation safety, in particular IDV influence effective communication in aviation safety (Hayward, 1999; Metscher et al., 2009). In addition, Li et al. (2007) stated that collectivistic culture or low IDV relates with bad problem solving particularly with collective decision making, so that individualistic culture have lower accident cause than collectivistic culture [12]. Collectivism which is often associated with high power distance is characterized by unwillingness to question the decision or action of leaders [1]. In addition, Soeters and Boer (2000) suggested that aviation safety was enhanced in individualistic culture [17]. They note that in collectivistic culture, the pre-disposition towards regulation led to an increased likelihood of accident.

The fact that Indonesian high MAS also influence aviation safety enrich analysis of global aviation safety. Relation between unsafe act-decision error and MAS can be seen from accident in 2008 . In this accident, pilot use his intuition to estimate fuel that must be carry on during the flight. This fact is in line with one indicator of Hofstede' masculinity that is a habit to use intuition during activity. Result of this study that LTO and IVR do not influence HFACS must be noted as well since in other non-Western culture (i.e., Chinese culture), LTO influence aviation safety [7]. The difference may due to different nature of Indonesia and China. Whereas China has high LTO, Indonesia has no clear pattern of LTO [3]. Similar reason for the absence of IVR in HFACS.

This study has several limitation worth noting. First, the accidents reports which have been analyzed restricted to year of 2001-2012 based on KNKT data. Further study with more complete and new data collection is needed to draw more concrete conclusions. Second, further study should be conducted in order to identify in which level the cultural factors are included within HFACS.

Overall, the evidence from this research supports the observation that national cultures have an impact on aviation safety. Further, the compability of national culture and aviation system is a must to obtain aviation safety. As stated by Jing and Batteau (2015) in cases of Chinese culture, crucial insights into national culture and how it manifests itself during flight operations is needed as well as highlighting ways in which Western technology and national culture clash within the cockpit [7].

\section{Conclusion}

Results of this study show that in cases of Indonesian aviation safety, culture plays an important role in aviation accidents investigation. For Indonesian aviation safety, this study gives valuable contribution in considering cultural factors during investigation process of aviation accident, in particular giving a new paradigm for KNKT. Implication of the study is that not to ignore cross-cultural issues in aviation safety. This study also give valuable insight of cultural role in global aviation safety. Countries having similar culture with Indonesia can learn from cases of Indonesia aviation safety. HFACS that is created based on Western culture is argued to be cultural bias. The challenge for aviation safety is not to ignore the cultural issue rather to manage the potential risk that may present.

\section{References}

1. Helmreich, R.L., Proceed. IATA Hum. Fctrs. Sem. 39-43 (1999)

2. Helmreich, R.L., Merrit, A.C., Culture at work in aviation and medicine: National, organizational, and professional influence (Aldershot, UK: Ashgate, 1998)

3. Hofstede, G. \& Hoftstede G.J., Cultures and Organizations - Software of the mind. (New York: McGraw-Hill USA 2010)

4. Hofstede, G., National Cultures and Corporate Cultures. In L.A. Samovar \& R.E. Porter (Eds.), Communication Between Cultures (Belmont, CA : Wadsworth 1984)

5. Hofstede, G., Cultural Constraints in Management Theories (The Academy of Management Executive 1993)

6. Hofstede, G., Psychology \& Culture, 2 (2011)

7. Jing, H., Batteau, A., The Dragon in the Cockpit: How Western Aviation Concepts Conflict with Chinese Value Systems (Ashgate Publishing, Ltd. 2015)

8. Jing, H.S., Lu, C.J., Peng, S.J., Hum. Fctrs. \& Aero. Safe., 1, 341-359 (2001)

9. Johnson A, Widyanti A., Ergonomics, 54, 509-518 (2010)

10. Klein, H.A., Cultural differences in cognition: Barriers in multinational collaborations (Lawrence Erlbaum, MArwah. 2005)

11. KNKT, Laporan Penyelidikan Kecelakaan Pesawat Udara. (Kementrian Perhubungan Republik Indonesia. 2013)

12. Li, W.C., Harris D., Chen A., Aviatn., Spc., Enviro., Med., 78, Sct. 1 (2007)

13. Reason, J., Human Error (Cambridge University, New York 1990)

14. Shappell, S.A. \& Wiegmann, D.A., Hum. Fctrs. \& Aero. Safe., 1, 59-86 (2001)

15. Shappell, S.A. \& Wiegmann, D.A., A human error analysis of general aviation controlled flight into 
terrain accidents occurring between 1990-1998 (Washington DC: Federal Aviation Administration, Office of Aviation Medicine 2003)

16. Shappell, S.A. et. al., Human Error and Commercial Aviation Accidents : An Analysis Using the Human Factors Analysis and Classification System (2007)

17. Soeters, J.L. and Boer, P.C., Int. J. Aviat. Psych., 10, 111-133 (2000)

18. Widyanti A, De Waard D, Johnson A, Mulder B., Ergonomics, 56, 182-194 (2013) 